\title{
Towards Sister City Cooperation between Cilacap and Mueang Chonburi District
}

\author{
Muhammad Yamin \\ Universitas Jenderal Soedirman \\ yamin.unsoed@gmail.com
}

\author{
Arum Tri Utami \\ Universitas Jenderal Soedirman \\ arumtriutami@gmail.com
}

\begin{abstract}
This research will attempt to elaborate the possibility of establishing sister-city cooperation between Cilacap District in Indonesia and Mueang Chonburi District in Thailand. The significance of this research is to identify the similarities between the two regions that are potential for inter-region cooperation and further foster their development. The Cilacap District is a coastal area located in Central Java, with fishery and tourism makes the major economic activities in this region. Chonburi province where Mueang Chonburi district is located in urban area with industry, agriculture and tourism as the major local activities.The activities in this research will comprise of; (1) identification of each local strength/activities that are potential for socio-cultural cooperation; (2) exploration of possible cooperation frameworks between the Mueang Chonburi District and Cilacap District; (3) socializations through FGD or hearing to endorse and further gain input from practitioners in this case local governments to implement the designed framework.
\end{abstract}

Keywords: Cilacap District, international cooperation, Mueang Chonburi District, sister city, coastal areas development.

\section{I.Background}

Sister City is a concept of cooperation between two cities or provinces in two different countries who share geographical or political characteristics. This sort of cooperation based on shared traits similar is commonly aimed to improve the relationship between cultures and individuals and in the long run spur the region's growth and development. Ideally Sister City facilitates networking in economic, culture, education, and various fields of cooperation in accordance with the core competencies of the involved cities (Obsatar Sinaga, 2010, viii).

The concept of partnership between cities began to grow in the 1960s, pioneered by President Dwight David Eisenhower of the United States to improve public diplomacy through people to people diplomacy (Zulkifli, 2012,4). There are many terms used to describe the pattern of foreign partnerships similar to sister city, like French uses the term Jumelage, United States and Mexico uses Sister City, Russia and the United Kingdom uses Twin Cities, Japan and China uses Friendship city and Germany uses partnerstade. All of these terms generally illustrates the cooperation of two cities as an activity of international community (Zulkifli, 2012, 4).

This research is interested to identify and further design a sister city cooperation framework for a region in Indonesia whose local strength has not been sufficiently developed. Cilacap is selected as the subject of research based on its geographical condition, potentials for tourism and the fact there are many rooms for improvement in those aspects. This region has not implemented a sister-city cooperation. Given that Cilacap is a coastal area, at its north is the Indian Ocean, it is famous for its tourism. Some most well-known recreational beaches in Cilacap are Teluk Penyu beach, Pasir Putih beach, and Nusakambangan island. In addition to that, the community makes living in fishery. The tourism in Cilacap has not been widely recognised; most of the visitors are domestic tourists. This district is currently attempting to promote its local tourism in order to boost the local economy. Cilacap District government so far has not done partnership with other districts abroad due to the lack of information about possible partners abroad. This results in the weak international outlook of Cilacap District. Furthermore, Cilacap administration has not made international cooperation their priority because they have tended to be inward-looking.1 Whereas according to the assumptions of researchers, it is time for2015. Regarding this issue, there are unlimited choices of foreign partners for Cilacap to establish sister-city cooperation. The district that is projected to be the sister city partner is Mueang District in Chonbury province, Thailand. The typical economic activity in the northern part of the Chonburi province is agriculture, while in the southern part, it is tourism. This province is famous for Pattaya which has been an international tourist destination. This makes sister city cooperation suitable for the two regions.

Sister City partnership does not only accelerate the economic development of both parties to cooperate but also expected to become a means to learn about the management of development cooperation fields, fosters active participation and

\footnotetext{
${ }^{1}$ Interview with Sindy Syakir, Head Commission on Cooperation in regional parliament of Cilacap on April
} 
initiative of the city local government, business and society. In addition to strengthening the friendly relations between the government and the people of both sides and give each other a chance to introduce their culture. By studying these things above, this research seeks to formulate a management framework Sister City partnership between Cilacap with Mueang Chonburi District, Thailand, and identify the stakeholders (stakeholders) that may be involved in these programs such as local government, businesses, and components of society in order to maximize the construction and development of the city as a whole.

\section{II.LITERATURE REVIEW}

\section{A.Paradiplomacy}

Paradiplomacy refers to the behavior and capacity to perform foreign relations or international activities with foreign parties conducted by the entity 'sub-state' or regional government/local government, to achieve specific interests (Wolff, 2009:1-2; Dickson, 2014). Mingus (2006) emphasizes that paradiplomacy is a matter of urgency especially since we are living in the age of globalization. With the growing breadth and capacity of local authorities, and more rapid flow of information, as well as the borderless capital movements and human migration between countries, it is inevitable for the provincial and district /city stakeholders to take part in international affairs. In a broader framework, paradiplomacy may lead to a democratization of foreign policy (Nganje, 2014).

Study on sub-state governments have been developed since 1980s (Kuznetsov, 2014), but the concept of Paradiplomacy was firstly developed by Ivo Duchacek and Panayotis Soldatos in 1990. According to Duchachek and Soldator, this terminology is used for activities that are parallel, coordinated, and complementary to, or even sometimes at odds with the macrodiplomacy carried out by the central government (Duchacek, 1990 and Soldatos,1990). Since the 1990s, Ivo Duchachek observed the role of sub-national governments in international relations that is getting more crucial. At least there are three reasons underlying these arguments: first, it is a matter of fact that the representatives of foreign countries always report to their government on the domestic issues that are affecting diplomatic relations between two states. Second, sub- national governments primarily the legislative organs are often the target of foreign intervention in the form of political and economic lobbies. Third, the interests of transnational corporations in securing business encourage them to build stronger relationship with sub-national governments.

\section{B. Sister City}

Sister city can be defined as a type of paradiplomacy where local government and administrations play a significant role in foreign relations. Sister city model was firstly introduced by USA in the 1960 s by President Eisenhower through the international program sister city aimed to involve local organizations or individuals to engage in international activities. The goal was to create a peaceful environment by bringing people closer. In practice, sub-state actors or the local government can be the executor for international cooperation or interlocutor who links the domestic and foreign stakeholders, when providing network and forums to help resolving troubles in existing relationships (Souder and Bredel, 2005). Cremer, et. al. (2001) posits that sister-city should be understood in the context of bridging the global and the local. In particular, global activities need to be projected to stimulate local development. For the region involved in sister city, various advantages to be achieved;

A wide range of benefits, both tangible and intangible, accrue to cities involved in sister-city relationships. among these are the benefits of international trade, cultural exchanges, educational exchanges, migration, investment and tourism (Cremer, et. al., 2001: 393).

The conceptual framework of stages in establishing sister city partnership was explained by Villiers (2009) as follows. Firstly, the actors design a coalition strategy in order to build a mutually accepted perception, vision and mission as well as partnership goal, partner selection, management and achieving goals through learning and networking. Secondly, identification of strategic partners and elaboration of the potentials to be built together through the partnership. Thirdly, evaluation or verification of the track record of past cooperation of the partner candidates. Fourthly, negotiations in selecting the partner, planning the future activities, and formulating agreement or momerandum of understanding. Fifthly, implementation of the agreement, where every plan is executed and further reevaluated. Sixthly, as a result of the previous stages, the municipality/province will obtain a certain level of cooperation capacity.

This idea has been since then adopted by many countries in the world not excluding Indonesia when the Bandung municipality signed the Sisterhood Charter (Piagam Persaudaraan) on June 1960 with the Braunschwieg municipality from Germany which also marked the first sister city cooperation by Indonesian government. Other sister city cooperation in Indonesia includes cooperation between Medan and Cengdu (China) agreed in 2002; and cooperation of business and investment promotion between Bogor and St. Louis (USA) agreed in 2004. On the topic of implementation of sister city, O'Toole (2001) highlights the importance of perception building regarding sister city. Particular perception on sister city will result in particular public policies.

There have been a lot of works analysing the practice of sister city and their impacts on local communities. Ramasamy and Cremer (1998) analyse the economic impact of sister city cooperation between New Zealand and its Asian partners and its significance in other fields, i. e. cultural activities, and tourism. Forth and Howell further emphasize how the particular type of sister-city will influence the results. A relationship which is cultural in nature, in this case Australia and China, will result in lesser extent of economic impact (Forth and Howell, 2000).One of the past researches on sister city in Indonesia was conducted by Windiani (2013), titled "Indonesian Foreign Relations in the age of Local Autonomy: Evaluation of "Sister Province between 
Central Java and Queensland state of Australia in 2000-2007. In this research Windiani mentions that the cooperation has been established in effective manner especially in the area of education. The major supporting factor for the cooperation was the opportunity and support provided by the central and local government. Another research undertaken by Stinjak, et. al. (2014) elaborates the potentials of establishing sister city partnership between Jakarta and Bandung and municipalities abroad aimed to improve the city's resilience.

These studies provide a great help for our research by outlining the stages and basic principles in establishing sister city. From the past studies, it can be learned that sister city can take different forms of activities, depending on the local potency that is wished to be developed or local strengths that are believed to be vital in the local society's life. Furthermore, although sister city is aimed to endorse people diplomacy, the role of government is still central, especially in providing institutional and legal framework for sister city.

\section{A.Method}

\section{III.RESEARCH METHOD}

Methods of research to be conducted is a qualitative method with descriptive form. Qualitative research method is a method of research that emphasize the quality or the most important thing of the nature of goods or services. A main feature of the goods or services are in the form of events or phenomena, moreover social phenomena is the meaning of the events that can be used as a lesson for the development of theoretical concepts. While the descriptive form used in this study intends to describe systematically, actual and accurate information on the facts, circumstances and events that are found in the field with coverage of the data, both qualitative and quantitative.

Based on the research question and purpose of this study, the design of the research is action research. Action research is one of research designs which is purposed to influence the performance or particular organizations, institutions or policy making (Fischer, et. Al., 2007). Singh (2005) posits the characteristics of action research includes; the participation of the practitioners being scrutinised in the research, and collaborative works among different group of people (Singh 2005, cited by Ficher, et. Al., 2007). The strength of action research is its commitment to finding solution of social problems occurring in societies (bryman, 2012). further explains that in an action research, several considerations are needed. They range from ethical issues and the obstacles in collecting data dealing with other counterparts. Data and technique of data collection

Drawing from the discussion on research activities above, it can be implied that the data collection will include enquiries of any relevant data to the local capacities. The purpose is identify the area in which sister-city cooperation may be carried out and the type of activities in the cooperation framework between the two regions. Source of data used in this research is secondary data. A secondary source is a source that does not directly provide data to data collectors through another person or through documents. Secondary sources obtained from the literature such as scientific journals, books, data from the Indonesian Embassy for Thailand, as well as the other documents related to this research, including data from the website of the Official Government Thailand and ASEAN Secretary.

The data that will be collected throughout the research varies, ranging from government official documents bearing information of local demography, socio-cultural characteristics and economic condition and development plan; perceptions of the government and the society about development; as well as other relevant information including the socio-cultural activities of the local communities.

Data collection is conducted through a literature review techniques by collecting secondary data from the literature, journals, books and news through electronic and mass media. Different data collection methods will be employed to gather the data above. First, government official documents will be collected through document enquiry or interview. This will be improved through direct observation at the local societies. As for the interview, structured interviews will be employed to view the perceptions of the government and the local societies. Subject of interviews include government from Department of Tourism, Planning and Development and other related bodies, local leaders and local communities. Furthermore, the authors use other secondary data in the form of official data from the Thailand government website and other official websites that support research.

\section{B.Technique of Analysis}

The selection of technique of analysis helps us to decide how we sort the collected data and how to make use of them to establish the final arguments and conclusion of the research. An action research aimed to intervene in policy making will overlook the data based on the values they represent. According to Fischer, et. Al. (2007), it is common used in analysing data obtained from observation, interview, and documents collection. By employing this technique of analysis, the socio-cultural aspect of each region found to be imperative for local development can be identified. Furthermore, it will help identifying the constraints and opportunities to endorse local government to accomplish the cooperation.

\section{IV.CONCLUSION}

Sister city is one of micro model cooperation used by twostates in the second track bilateral diplomacy which focuses on enhancing development in the two states. Foundations of sister city or sister province cooperation include resemblance in administration, socio-cultural or geographical characteristics or similarities in problems faced by the publics. In the globalisation era, interconnectivity between states would become a tool to develop local potentials and solve local problems.

This research will attempt to elaborate the possibility of establishing sister-city cooperation between Cilacap District in 
Indonesia and Mueang Chonburi District in Thailand. The significance of this research is to identify the similarities between the two regions that are potential for inter-region cooperation and further foster their development. The result of this research is to make a good relationship and take the advantages with this sister city like economy, tourism and other advantages.

The expected outcome of the research is a comprehensive framework for sister city cooperation in coastal region as well as policy paper to be presented to both local governments. The urgency of this research also lies on its contribution to paradiplomacy study and its role in local development, thus several academic papers will be produced in the end of the study.

\section{REFERENCES}

[1] Bryman, A. (2012). Social research Method, 4th Edition. Oxford: Oxford University Press.

[2] Casson, R., \& Dardanelli, P. (2012). Local Government Paradiplomacy in the UK: The Case of the Kent-Virginia Project. Local Government Studies, 38(5), 599-614.

[3] Costello, P. J. M. (2003). Action research. London, New York: Continuum.

[4] Dickson, F. (2014). The Internationalisation of Regions: Paradiplomacy or Multi - level Governance?. Geography Compass, 8(10), 689-700.

[5] Duchacek, Ivo. (1990). "Perforated Sovereignties: Towards a typology of New Actors in International Relations." In Federalism and International Relations: the Role of Subnational Units, ed. Hans Michelmann and Panayotis Soldatos. Oxford: Claredon Press:1-33.

[6] Eatmon, T. D. (2009). Paradiplomacy and Climate Change: American States as Actors in Global Climate Governance. Journal of Natural Resources Policy Research, 1(2), 153-165.

[7] Fischer, F., Miller, G. J. and Sidney, M. S. (Ed.) (2007). Handbook of Public Policy Analysis: Theory, Politics and Methods. London, New York: CRC Press.

[8] Forth, G., \& Howell, K. (2001). The importance of Sino-Australian sister city type relationships in regional development. Regional policy and practice, 10(1), 16-24.

[9] Kuznetsov, A. S. (2015). Theory and Practice of Paradiplomacy Subnational governments in international affairs. New York, Oxon: Routledge.

[10] Miles, M.B. \& Huberman A.M. (1984). Qualitative data Analysis. California: Saga Publication.

[11] Mingus, M. S. (2006). Transnationalism and subnational paradiplomacy: are governance networks perforating sovereignty?. Intl Journal of Public Administration, 29(8), 577-594.

[12] Mukti, T.A. (2013). Paradiplomacy, Kerjasama Luar Negeri oleh Pemda di Indonesia.

[13] Yogyakarta: Phinisi Press.

[14] Nganje, F. (2014). Paradiplomacy and the democratisation of foreign policy in South Africa.

[15] South African Journal of International Affairs, 21(1), 89-107.

[16] O'Toole, K. (2001) Kokusaika and Internationalisation: Australian and Japanese Sister City Type Relationships, Australian Journal of International Affairs, 55:3, 403-419.

[17] Ramasamy, B. and R. D. Cremer. (1998). Cities, commerce and culture: The economic role of international sister - city relationships between New Zealand and Asia, Journal of the Asia Pacific Economy, 3:3, 446-461.

[18] Sinaga, Obsatar. (2010). Otonomi Daerah dan Kebijakan Publik: Implementasi Kerjasama Internasional. Bandung: Lepsindo.

[19] Sitinjak, E., Sagala, S., \& Rianawati, E. (2014). Opportunity for Sister City Application to Support Resilience City.

[20] Soldatos, Panayotis. (1990).An Explanatory Framework for the Study of Federal States as Foreign-policy Actors. In: Federalism and International
Relations: the Role of Subnational Units,Michelmann, Hans and Panayotis Soldatos, eds. Oxford: Claredon Press: 34-53.

[21] Souder, Donald Bell; Shanna Bredel \& Laurel Rasplica Rodd. (2005). A Study of Sister City Relations. A Research Paper of Asian Languages and Civilizations in University of Colorado.

[22] Villiers, J.C. (2009). Success Factors and the City-to-City Partnership Management Process - From Strategy to Alliance Capability. Habitat International, 33(2), 149-156.

[23] Windiani, Reni. (2013). "Hubungan Luar Negeri Indonesia Era Otonomi Daerah, Studi Evaluasi Hubungan Sister Province (Provinsi Kembar) Jawa Tengah Dengan Negara Bagian Queensland Australia Periode Tahun 2002007. Jurnal Politika 2.1(2013): 76-98.

[24] Wolff, S. (2007). Paradiplomacy: scope, opportunities and challenges. The Bologna Center Journal of International Affairs, 10(1), 141-150.

[25] Zulkifli. (2012). Thesis. Kerjasama Internasional sebagai Solusi Pengelolaan Kawasan Perbatasan Negara (Studi Kasus Indonesia). Jakarta: Universitas Indonesia. 